\title{
INTENSITAS PERILAKU MEROKOK REMAJA PUTRI DITINJAU DARI KONFORMITAS
}

Fahmi Islami fahmiamy4@gmail.com

\author{
TA. Prapancha Hary
}

\begin{abstract}
This study aims to determine with more certainty on the smoking behavior of young women in terms of conformity, so as to provide an overview and map the sequence of events underlying the young women who smoke.

Subjects in this study of young women aged 12-17 years who had a smoking behavior. This study used a single subject as a teenager and using a phenomenological approach, and using the techniques of data collection using interviews and observations.

The research results of this study at the beginning of the subject smoking because seeing parents who smoke, when the subject of interest because the subject feels when parents smoke looks very calm and relaxed. So there is no effect of conformity, because the subject knows his friends when the subject had smoked.
\end{abstract}

Keywords: Smoking Behavior, Young Women, Conformity

\section{INTISARI}

Penelitian ini bertujuan untuk mengetahui dengan lebih pasti perilaku merokok pada remaja putri yang ditinjau dari konformitasnya, sehingga dapat memberikan gambaran serta memetakan rentetan peristiwa yang melatarbelakangi remaja putri yang merokok.

Subjek dalam penelitian ini remaja putri berusia 12-17 tahun yang memiliki perilaku merokok. Penelitian ini menggunakan sebanyak satu subjek remaja dan menggunakan pendekatan fenomenologi, dan menggunakan tehnik pengumpulan data menggunakan wawancara dan observasi.

Hasil penelitian dari penelitian ini pada awal subjek merokok karena melihat orangtuanya yang merokok, saat itu subjek tertarik karena subjek merasa ketika orangtuanya merokok terlihat sangat tenang dan santai. Sebelum subjek mengenal teman-temannya saat itu subjek sudah merokok.

Kata kunci: Intensitas Perilaku Merokok, Remaja Perempuan, Konformitas 


\section{PENDAHULUAN}

Sejak dilahirkan, manusia membutuhkan pergaulan dengan orang lain untuk memenuhi kebutuhan-kebutuhan hidupnya (Gerungan, 1996). Terutama pada masa remaja yang merupakan masa peralihan yaitu antara masa anak-anak ke masa dewasa. Pada saat inilah individu itu mengalami pertumbuhan yang cepat, baik dari segi fisik maupun psikologis. Remaja juga bukan lagi sebagai kanak-kanak, dalam arti luar ditinjau dari segi postur fisik, sikap dan perilakunya, namun remaja juga belum dapat dikatakan dewasa. Jaman sekarang remaja lakilaki dan remaja perempuan sudah tidak memiliki perbedaan kecuali perbedaan jenis kelamin, perilaku merokok pada remaja laki-laki dianggap sudah biasa dikalangan umum, bahkan sekarang banyak pula remaja perempuan yang merokok di depan umum.

Perilaku merokok dimasukkan ke dalam berbagai golongan perilaku yang tidak mendukung tercapainya kualitas hidup dan well-being (kesejahteraan) manusia (WHO, 2005; WHO, 2012). Beberapa sumber menyebut perilaku merokok sebagai (1) perilaku berkompromi terhadap kesehatan (Taylor, 2006), (2) perilaku berisiko kesehatan dan kematian (Hair dkk, 2009; WHO, 2012), (3) perilaku tidak sehat (Hardy, 2009), dan (4) gangguan penyalahgunaan dan ketergantungan zat (Davison, Neale, \& Kring, 2006). Sebutan-sebutan ini muncul karena merokok terbukti mempunyai dampak negatif pada kesehatan dan hal-hal lainnya. Dampak negatif kesehatan tersebut sangat luas meliputi kesehataan fisik dan mental, kesehatan indvidual dan masyarakat (MacKay dan Eriksen, 2002).

Sarafino (2008) menjelaskan bahwa remaja mulai merokok disebabkan oleh beberapa faktor, antara lain orang tua dan teman yang merokok, peniruan terhadap seseorang yang diidolakan seperti bintang film, atau artis yang merokok (Distefan dkk., 1999), dan remaja mencoba menghisap rokok untuk pertama kalinya untuk menyesuaikan diri atau berkonformitas terhadap teman sebaya (Leventhal dkk., 1985).

Konformitas merupakan suatu keadaan dimana seseorang mengubah sikap dan tingkah laku agar sesuai dengan norma sosial yang berlaku dengan tujuan agar mendapatkan penerimaan oleh kelompok sosial (Baron \& Byrne, 2005). Konformitas terdiri dari dua dimensi (Baron \& Byrne, 2005), yaitu normative social influence dan informational social influence. Normative social influence adalah konformitas yang didasarkan pada keinginan individu untuk disukai dan diterima oleh orang lain dengan tujuan menghindari penolakan 
dan mendapatkan penerimaan, dapat dilihat dari perilaku seperti mengerjakan tugas dalam kelompok agar dianggap dapat bekerja sama dengan baik.

Konformitas merupakan hal yang seringkali terjadi pada masa remaja, yaitu di saat remaja bergabung ke dalam sebuah kelompok teman sebaya untuk mendapatkan penerimaan dan pertemanan dalam menentukan identitas dirinya (Brown dalam Simons \& Farhat, 2010). Remaja merupakan masa transisi dari anak-anak menuju dewasa yang berlangsung pada usia 10-20 tahun yang diperhadapkan dengan tahap perkembangan indentity versus identity confusion (Erickson dalam Santrock 2003).

Perilaku merokok pada remaja umumnya semakin meningkat sesuai dengan bertambahnya frekuensi dan intensitas merokok yang sering mengakibatkan mereka mengalami adiksi rokok (Laventhal dan Cleary dalam Hasnida dan Kemala, 2005). Remaja perempuan biasanya mulai mencoba rokok pada usia 10-14 tahun. Penelitian dari berbagai negara menunjukkan bahwa faktor yang mendorong untuk memulai merokok amat beragam, baik berupa faktor dari dalam dirinya sendiri (personal), sosio kultural dan pengaruh kuat dari lingkungannya. Faktor dari dalam remaja dapat dilihat dari kajian perkembangan remaja. Remaja mulai merokok dikatakan oleh Erikson (Gatchel, 1989) berkaitan dengan adanya krisis aspek psikososial yang dialami pada masa perkembangannya yaitu masa ketika mereka sedang mencari jati dirinya. Dalam masa remaja ini sering dilukiskan sebagai masa badai dan topan karena ketidaksesuaian antara perkembangan fisik yang sudah matang dan belum diimbangi oleh perkembangan psikis dan sosial. Upaya-upaya untuk menemukan jati diri tersebut, tidak semua dapat berjalan sesuai dengan harapan masyarakat.

Dari hasil wawancara awal peneliti dengan subjek penelitian menghasilkan asumsi tentang faktor perilaku merokok. DN, 17 tahun, mengatakan bahwa sejak berusia 9 tahun subjek mulai merokok. Awalnya hanya terpengaruh dengan teman-teman. Sejak kecil keluarganya memberi kebebasan kepadanya untuk berteman dan melakukan aktivitas bersama teman karena sibuk bekerja. Ayah subjek satu-satunya perokok di rumah. Awalnya hanya karena rasa ingin tahu rasa rokok saat melihat ayahnya merokok dan mengurangi beban pikiran saat sedang menghadapi masalah namun hingga saat ini subjek tidak pernah berhenti merokok. Selain itu, ayah subjek juga seorang perokok. Namun hingga saat ini perilaku merokok subjek dirahsiakan dari orang tuanya. Saat ini subjek tidak pernah mendapat keluhan penyakit akibat merokok.

Menurut Kesowo (2003), rokok adalah hasil olahan tembakau yang terbungkus, sejenis cerutu atau bentuk lainnya yang dihasilkan dari tanaman Nicotiana Tabacum, Nicotiana Rustica dan sejenisnya. Sedangkan Menurut Oskamp (dalam Susmiati; 2003) mengatakan perilaku merokok adalah kagiatan 
menghisap asap tembakau yang telah menjadi cerutu kemudian disulut api. Tembakau berasal dari tanaman nicotiana tabacum. Menurutnya ada dua tipe merokok, pertama adalah menghisap rokok secara langsung yang disebut perokok aktif, dan yang kedua mereka yang secara tidak langsung menghisap rokok, namun turut menghisap asap rokok disebut perokok pasif.

Perilaku merokok adalah membakar tembakau yang kemudian dihisap, baik menggunakan pipa ataupun rokok (Sitepoe, 2000).

Dari definisi di atas dapat disimpulkan bahwa merokok adalah kegiatan membakar tembakau dari rokok yang melibatkan proses memasukkan asap ke dalam tubuh dengan cara menghisapnya.

Menurut Cialdini \& Goldstein (Taylor, dkk, 2009), konformitas adalah tendensi untuk mengubah keyakinan atau perilaku seseorang agar sesuai dengan perilaku orang lain.

Kartono dan Gulo (2000), konformitas adalah kecenderungan untuk dipengaruhi tekanan kelompok dan tidak menentang norma-norma yang telah digariskan oleh kelompok. Seseorang melakukan konformitas terhadap kelompok hanya karena perilaku individu didasarkan pada harapan kelompok atau masyarakat.

Zebua dan Nurdjayadi (2001), konformitas adalah suatu tuntutan yang tidak tertulis dari kelompok teman sebaya terhadap anggotanya tetapi memiliki pengaruh yang kuat dan dapat menyebabkan munculnya perilaku-perilaku tertentu pada anggota kelompok.

Dari uraian mengenai berbagai pengertian "konformitas" diatas, dapat disimpulkan bahwa konformitas adalah suatu bentuk sikap penyesuaian diri seseorang dalam masyarakat/kelompok karena dia terdorong untuk mengikuti kaidah-kaidah dan nilai-nilai yang sudah ada.

Kata intensitas berasal dari Bahasa Inggris yaitu intense yang berarti semangat, giat (John M. Echols, 1993: 326). Sedangkan menurut Nurkholif Hazim (2005: 191), bahwa: "Intensitas adalah kebulatan tenaga yang dikerahkan untuk suatu usaha". Jadi intensitas secara sederhana dapat dirumuskan sebagai usaha yang dilakukan oleh seseorang dengan penuh semangat untuk mencapai tujuan.

Perilaku merokok adalah membakar tembakau yang kemudian dihisap, baik menggunakan pipa ataupun rokok (Sitepoe, 2000). Dari definisi di atas dapat disimpulkan bahwa merokok adalah kegiatan membakar tembakau dari rokok yang melibatkan proses memasukkan asap ke dalam tubuh dengan cara menghisapnya.

Faktor lingkungan dapat didapat dari konformitas, masyarakat sekitar, tetapi perilaku merorkok lebih banyak didapat dari konformitas. Pengertian konformitas yaitu Kartono dan Gulo (2000), konformitas adalah kecenderungan 
untuk dipengaruhi tekanan kelompok dan tidak menentang norma-norma yang telah digariskan oleh kelompok. Seseorang melakukan konformitas terhadap kelompok hanya karena perilaku individu didasarkan pada harapan kelompok atau masyarakat.

Zebua dan Nurdjayadi (2001), konformitas adalah suatu tuntutan yang tidak tertulis dari kelompok teman sebaya terhadap anggotanya tetapi memiliki pengaruh yang kuat dan dapat menyebabkan munculnya perilaku-perilaku tertentu pada anggota kelompok.

Berdasarkan uraian di atas, maka dapat disimpulakan bahwa perilaku merokok pada remaja putri yang dipengaruhi oleh konformitas. Perilaku merokok yang dipengaruhi oleh konformitas yang terjadi pada remaja putri di lakukan hanya karena perilaku individu didasarkan pada harapan kelompok atau masyarakat, karena konformitas memiliki penagruh yang kuat dan dapat menyebabkan munculnya perilaku-perilaku tertentu pada anggota kelompok.

\section{METODE PENELITIAN}

Peneliti menggunakan subjek penelitian dengan ciri-ciri sebagai berikut: Usia subjek 17 tahun, Subjek berjenis kelamin perempuan, Subjek duduk dibangku kelas 2 SMA, Memiliki perilaku merokok selama 9 tahun, Subjek termasuk tipe perokok sedang, dan jenis rokok yang dihisap subjek rokok putih (mentol).

Penelitian ini menggunakan metode pengumpulan data pada natural setting (kondisi yang alamiah), sumber data primer, wawancara mendalam (indepth interview) dan semiterstruktur (semistructure interview), observasi partisipan (participant observation) pasif, serta dokumentasi. Selain itu, untuk menguji kredibilitas penelitian, dilakukan juga triangulasi data terhadap pihakpihak yang terkait dengan subjek.

Penelitian dengan judul "Intensitas Perilaku Merokok Remaja Perempuan Ditinjau dari Konformitas" ini menggunakan teknik analisis data mengacu pada teori lapangan yang dikemukakan Miles dan Huberman (1992), yaitu reduksi data, penyajian data, dan penarikan kesimpulan. Selain itu, penelitian ini juga menggunakan teknik analisis data melalui koding.

\section{HASIL PENELITIAN}

Subjek penelitian berjenis kelamin perempuan yang merokok sejak berusia 9 tahun. Karena melihat Ayah subjek yang merokok. subjek berusia 17 tahun, 
subjek berinisial DN,bersekolah di SMA Swasta di Yogyakarta, dan pendidikan terakhir subjek SMP Negri di Yogyakarta.

Subjek adalah orang yang mandiri dan bertanggung jawab, subjek tidak mau tergantung kepada orang tuanya, subjek juga termasuk orang yang mudah bergaul atau supel. Subjek memiliki banyak teman dan sangat terbuka kepada orangtuanya. Subjek tidak pernah menutup dirinya, subjek orang yang apa adanya. Subjek juga tidak pernah membeda-bedakan teman. Bahkan adik dan kakak subjek mengetahui kalau subjek merokok, tetapi orangtua subjek tidak mengetahui kalau subjek merokok, subjek tinggal bersama kedua orang tuanya beserta kakak dan adiknya, tempat tinggal subjek cukup luas dan bertingkat, subjek memiliki kamar sendiri dan berada di lantai atas rumahnya, sehingga setiap kali subjek merokok pada saat di rumah subjek selalu merokok di kamarnya sendiri

\section{Pembahasan}

Tipe perilaku merokok berdasarkan Management of affect theory Mu'tadin (2012) adalah:

Tipe perokok yang dipengaruhi oleh perasaan positif. Menurut Green tiga sub tipe ini adalah: Pleasure relaxation, adalah perilaku merokok untuk menambah atau meningkatkan kenikmatan yang sudah didapat. Subjek merasa nyaman ketika sedang merokok dan subjek merasa perilaku merokok itu enak. Kedua, Stimulation to pick them up adalah perilaku merokok yang dilakukan sekedarnya untuk menyenangkan perasaan. Subjek juga merasa lebih tenang saat merokok. Ketiga, pleasure of handling the cigarette adalah kenikmatan yang diperoleh dengan memegang rokok. Sangat spesifik pada perokok pipa. Perokok pipa akan menghabiskan waktu untuk mengisi pipa dengan tembakau sedangkan untuk menghisapnya hanya dibutuhkan waktu beberapa menit saja. Atau perokok lebih senang berlama-lama untuk memainkan rokoknya dengan jari-jarinya lama sebelum ia nyalakan dengan api. Keempat, perilaku merokok yang Kelima, dipengaruhi oleh perasaan negatif, subjek merasa bisa menyalihkan dengan merokok. Subjek merasa dengan merokok subjek merasa terlalu memikirkan masalahnya maupun ketika subjek mendapatkan tugas dari sekolah. Keenam, Perilaku merokok yang adiktif (psychological addiction) Subjek biasa menghabiskan satu bungkus rokok setiap harinya. Subjek biasanya akan merokok lebih dari satu bungkus apabila sedang berkumpul bersama teman-temannya. Ketujuh, Perilaku merokok yang sudah menjadi kebiasaan. Subjek menggunakan rokok sama sekali bukan karena untuk mengendalikan perasaan mereka, tetapi 
karena benar-benar sudah menjadi kebiasaannya rutin atau tanpa dipikirkan dan tanpa disadari.

\section{KESIMPULAN DAN SARAN Kesimpulan}

Penelitian ini dilakukan untuk mengetahui perilaku merokok remaja putri ditinjau dari konformitas. Peneliti menggunakan satu subjek perempuan berusia 17 tahun. Subjek merokok sejak sekolah dasar, karena terbiasa melihat orangtuanya yang perokok.

Dari penelitian di atas awal subjek merokok karena melihat orangtuanya yang merokok, saat itu subjek tertarik karena subjek merasa ketika orangtuanya merokok terlihat sangat tenang dan santai.

\section{Saran}

Orangtua. Sebaiknya orangtua lebih dapat menutupi perilaku merokok di depan anaknya yang masih kecil, agar anak tidak mengikuti kebiasaan buruk orangtua. Orangtua harus terbuka dan memberi pengertian bahaya merokok kepada anak, dan orangtua dapat lebih mengenal teman-teman anaknya.

Subjek. Remaja perempuan sebaiknya mengurangi intensitas merokok yang berlebihan, karena dapat menyebabkan ketergantungan dan gangguan pada kesehatan. Apabila mengalami permasalahan subjek dapat berkonsultasi dengan orangtua.

Peneliti Selanjutnya. Untuk peneliti selanjutnya, apabila tertarik untuk meneliti tentang perilaku merokok remaja putri yang ditinjau dari konformitasnya, semoga dapat dijadikan referensi untuk peneliti selanjutnya yang hendak meneliti hal yang sama. 


\section{DAFTAR PUSTAKA}

Albery, I.P., dan Munafo, M., 2007, Psikologi Kesehatan, edisi ke-1, Palmall, Yogyakarta, hal : $211-212$

Aula, L.E. 2010. Stop Merokok! (sekarang atau tidak sama sekali).Yogyakarta : Garailmu.

Baron, R.A., \& Byrne, D. 2005. Psikologi Sosial. Jilid II Edisi Kesepuluh (terjemahan Djuwita, R). Jakarta: Erlangga.

Chaedar. 2002. Pokoknya Kualitatif. Bandung : Pustaka Jaya.

Davison,G.C., Neale,J.M. dan Kring,A.M. (2006). Psikologi abnormal (9th ed.). Jakarta: PT Raja Grafindo Persada.

Denzin, N. K. 2009. The Research Act: A Theoretical introduction in Socialogical Methods. Mc Graw-Hills. New York

Kartono. 1999. Kamus Lengkap Psikologi. Jakarta : PT Raja Grafindo Persada

Kartono, K \& Gulo, D. 2000. Kamus Psikologi. Bandung: Pionir Jaya

Kesowo, L. F . Faktor Faktor yang Mempengaruhi Perilaku Merokok pada Pelajar Putra SMK di Kota Wonogiri. Skripsi tidak diterbitkan. Semarang: Program Studi Ilmu KeperawatanUNDIP, 2004.

Laksana. 2011. Hubungan Antara Tipe Keperibadian Terhadap Perilaku Merokok Pada Mahasiswa Program Studi Ilmu Keperawatan Universitas Muhammadiyah Yogyakarta. Karya Ilmiah. Yogyakarta. Fakultas 
Kedokteran dan Ilmu Kesehatan. Universitas Muhammadiyah Yogyakarta.

Lexy, J. 2002.Metodologi Penelitian Kualitatif. Bandung : PT. Remaja

Leventhal, G.S., Karuza, J., \& Fry, W.R. 1985. Beyond Fairness: A Theory of Allocation Preferences. In G. Mikula (Editor), Justice and Social Interaction: 167-218, New York: Springer-Verlag.

Mu'tadin, Z. (2002). Remaja dan rokok, www.e-psikologi.com. Diambil Pada Tanggal 13 Juni 2014.

Miles dan Huberman, A. 1992. Analisis Data Kualitatif: Buku Sumber Tantang Metode-Metode Baru. Jakarta:UI Press.

Moleong. 2010. Metode Penelitian Kualitatif. Bandung: PT. Remaja Rosdakarya

Nasution, I.K. (2007). Perilaku merokok pada remaja. Medan: Fakultas Kedokteran Universitas Sumatera Utara.

Nawawi dan Martini. 1991. Instrumen Penelitian Bidang Psikologi. Gajah Mada University Press.

Riduwan.2003. Skala Pengukuran Variabel-variabel Penelitian.Bandung : Alfabetta.

Simons-Farhat, B.G., Chen, R., Abroms, L., \& Haynic, D.L., 2010, Latent growth curve analyses of peer and parent influences on smoking progression among early adolescents, Health Psychol., 23, 612-621 cit.

Santrock, John W (2003). Adolescence; Perkembangan Remaja. Jakarta :Erlangga

Sitepoe, M (2000). Kekhususan Rokok Indonesia, PT. Gramedia widiasarana Indonesia, Jakarta.

Sarafino, Edward P. (2008). Health Psychology : Biopsychososial Interactions 6th Edition. New York : John Wiley \& Soni Inc.

Susmiati. Hubungan antara Stress Psikis dengan Perilaku Merokok pada Remaja Siswa SMK PGRI Singosari Kab. Malang. Skripsi, Fakultas Kedokteran Universitas Brawijaya Malang, 2003.

Sears, D.O., Feedman, J.L., \& Peplau, L.A. 1994. Psikologi Sosial. Jilid 2 Edisi Kelima (terjemahan Michael Adryanto). Jakarta: Erlangga 
Patton. (1980). Pengorganisasian Ke Dalam Suatu Pola. Yogyakarta:Graha Ilmu

Taylor, S.E., Peplau, L.A \& Sears, D.O. 2009. Psikologi Sosial Edisi XII. Jakarta: Kencana

Triyono, 2004. Identifikasi aspek perilaku merokok, PT.Elex Media Komputindo, Jakarta.

W. Gulo. 2004. Metodologi Penelitian. Jakarta; Grasindo

WHO. (2005). WHO Framework Convention onTobaccoControl.Geneva: WHO Library Cataloguing-in-Publication Data

WHO. (2012). World Health Statistics 2012. Report. Geneva: WHO

Zebua, A.S \& Nurdjayadi, R.D. 2001. Hubungan antara Konformitas dan Konsep Diri dengan Perilaku Konsumtif pada Remaja Putri. Jurnal Phronesis 